\title{
DETERMINAN PREFERENSI PUBLIK DALAM PEMILIHAN LOKASI PERUMAHAN TERJANGKAU BERSUBSIDI DI KOTA BANDA ACEH
}

\author{
Taufiq Saidi ${ }^{1)}$, Sugiarto Sugiarto $^{2)}$, Muhammad Razuli $^{3)}$, Lulusi $^{4)}$ \\ ${ }^{1,2,4)}$ Jurusan Teknik Sipil, Universitas Syiah Kuala \\ ${ }^{3)}$ Dinas Perumahan Rakyat dan Kawasan Permukiman Aceh \\ Corresponding email: sugiarto@unsyiah.ac.id
}

DOI: http://dx.doi.org/10.29103/tj.v9i1.188

\begin{abstract}
Abstrak
Ketersediaan perumahan untuk masyarakat merupakan indikasi pembangunan nasional, dan menjadi tujuan pemerintah Indonesia, termasuk di Kota Banda Aceh, ibukota provinsi Aceh untuk menyediakan perumahan bagi keluarga dengan pendapatan rendah yang terjangkau. Untuk tujuan ini, pemerintah memperkenalkan skema perumahan terjangkau bersubsidi guna meningkatkan kepemilikan perumahan untuk masyarakat. Namun, terlepas dari langkah-langkah ini, perumahan di Kota Banda Aceh telah banyak terbangun dan tersebar hingga ke pinggiran kota dengan standar kondisi perumahan yang sangat variatif baik dari kelayakan bangunan rumah, fasilitas prasarana dan sarana pendukungnya. Variasi ini terjadi dikarenakan pengembang (developer) dari masing-masing lokasi perumahan terjangkau menawarkan lokasi, tipe rumah yang dibangun, fasilitas yang disediakan, serta harga dan cara pemilikan rumah yang berbeda-beda. Oleh karena itu, paper ini bertujuan untuk mengidentifikasi determinan preferensi publik atau masyarakat dalam pemilihan lokasi perumahan terjangkau sehingga faktor determinan tersebut dapat dijadikan sebagai pertimbangan aspek yang harus disediakan oleh pengembang. Kajian ini dilakukan di Banda Aceh dengan target responden adalah penduduk masuk ke Kota Banda Aceh dengan jumlah sampel sebanyak 150 jiwa. Kuesioner disebarkan dengan mengadopsi teknik sampling acak berstrata (stratified random sampling). Determinan yang dikaji adalah faktor aksesibilitas, kelengkapan prasarana dan sarana, fasilitas, kondisi lingkungan, harga dan pelayanan, dan bangunan. Metode analisis faktor Principle Component Analysis (PCA) digunakan untuk mengeksplorasi hubungan antar faktor dengan indikator pemilihan lokasi perumahan terjangkau. Hasil empiris menunjukkan bahwa determinan preferensi publik yang dominan dalam pemilihan lokasi perumahan adalah faktor aksesibilitas dan pelayanan dengan varian sebesar $24.8 \%$, kelengkapan sarana dan prasarana dengan varian $18.95 \%$ dan fasilitas dan kepemilikan rumah dengan varian $16.51 \%$. Ketiga faktor tersebut menentukan keputusan konsumen dalam pemilihan lokasi perumahan terjangkau dengan varian total $60 \%$. Hasil empiris menunjukkan bahwa masyarakat cenderung memilih lokasi perumahan karena faktor aksesibilitas ke pusat perbelanjaan dan sarana dan prasarana yang ditawarkan oleh pengembang seperti ketersediaan jaringan listrik, air bersih dan persampahan menjadi indikator utama penentu pemilihan lokasi oleh konsumen.
\end{abstract}

Kata kunci: Perumahan terjangkau, Determinan, Preferensi,

\begin{abstract}
Housing affordability for the community indicates a national development, and it is the goal of the Indonesian government, including in the city of Banda Aceh, the capital of Aceh province to provide affordable housing for the low-income households. To do so, therefore, the government has introduced affordable subsidized housing schemes to enhance housing provide for the public. However, apart from
\end{abstract}

Determinan Preferensi Publik Dalam Pemilihan Lokasi Perumahan Terjangkau Bersubsidi di Kota Banda Aceh - Taufiq Saidi, Sugiarto Sugiarto, Muhammad Razuli, Lulusi 


\begin{abstract}
these steps, the housing location in Banda Aceh City has been constructed and spread up to the suburbs with a various standard of housing conditions both from the feasibility of houses, infrastructures and supporting facilities. This variation occurs because the developers of each housing locations offer difference attracted locations, types of houses, facilities provided, and prices and ways of ownership scheme. Therefore, this paper aims to identify determinants of public or community preferences in the selection of affordable housing locations. Then, the determinant factors could be used as consideration of aspects that must be provided by the developer. This study was conducted in Banda Aceh with the target of respondents being residents entering the city of Banda Aceh with a total sample of 150 people collected. The questionnaire was distributed by adopting stratified random sampling. The determinants examined in this study are accessibility factors, completeness of infrastructure and facilities, environmental conditions, prices and services, and the housing building itself. The factor analysis of Principle Component Analysis (PCA) approach is employed to explore the relationship between factors with indicators of the selection of affordable housing locations. The empirical results show that the central determinant of public preference in choosing housing locations is accessibility and service factors with a variance up to $24.8 \%$ from the total variance, followed by complete facilities and infrastructure with variance accounting up to $18.95 \%$ and facilities and home ownership with variance about $16.51 \%$ from the total. These three factors determine consumer decisions in the selection of affordable housing locations with a total variant of $60 \%$. Empirical results reveal that public tend to choose housing locations because accessibility factors to shopping centers and facilities and infrastructure offered by developers including the availability of electricity, availability clean water and waste disposal. These variables are the main indicators for determining housing location choices by consumers.
\end{abstract}

Keywords: Affordable Housing, Determinants, Preferences, Housing Locations, PCA, Banda Aceh.

\title{
1. Latar Belakang
}

Kecukupan dan kualitas perumahan merupakan indikasi produktivitas, kesejahteraan dan kemakmuran masyarakat. Bagi mereka yang berpendapatan rendah perumahan adalah bentuk kebutuhan. Namun, bagi mereka yang berpendapatan tinggi, kepemilikan rumah dipandang sebagai suatu investasi (Woo dkk. 2014). Perumahan yang dibeli atau bangun sendiri mewakili investasi paling mahal yang dilakukan. Di sisi lain bagi para penyewa rumah, sewa seringkali menjadikan beban seiring dengan biaya penyewaan yang selalu naik. Ketersediaan perumahan untuk masyarakat merupakan indikasi pembangunan nasional, dan menjadi tujuan pemerintah Indonesia, termasuk di Kota Banda Aceh, ibu kota provinsi Aceh untuk menyediakan perumahan bagi keluarga dengan pendapatan rendah yang terjangkau. Menurut Glaeser dan Gyourko (2003) pengembangan atau pembangunan perumahan perlu dibedakan untuk beberapa kalangan misalnya perumahan untuk yang berpenghasilan tinggi, perumahan berpenghasilan menengah dan perumahan berpenghasilan rendah. Sebagaimana tertuang dalam Undang-undang Dasar Negara Republik Indonesia Tahun 1945 pasal 28, bahwa rumah adalah salah satu hak dasar rakyat dan oleh karena itu setiap warga negara berhak untuk bertempat tinggal dan mendapat lingkungan hidup yang baik dan sehat.

Di Banda Aceh, umumnya pembangunan perumahan kecenderungannya dilakukan oleh pengembang (developer) dan pengembangan perumahan baru mengarah pada lokasi di pinggiran kota (sub urban) dikarenakan keterbatasan

Determinan Preferensi Publik Dalam Pemilihan Lokasi Perumahan Terjangkau Bersubsidi di Kota Banda Aceh - Taufiq Saidi, Sugiarto Sugiarto, Muhammad Razuli, 
lahan dan pembiayaannya. Selain itu, pengembang lebih cenderung mengembangkan perumahan untuk mereka yang berpendapatan rendah melalui program pemerintah dengan rumah bersubsidi. Pemerintah telah memperkenalkan skema perumahan terjangkau bersubsidi guna meningkatkan pasokan perumahan untuk masyarakat. Namun, terlepas dari langkah-langkah ini, perumahan di Kota Banda Aceh telah banyak terbangun dan tersebar hingga ke pinggiran kota dengan standar kondisi perumahan yang sangat variatif baik dari kelayakan bangunan rumah, fasilitas prasarana dan sarana pendukungnya. Variasi ini terjadi dikarenakan pengembang (developer) dari masing-masing lokasi perumahan terjangkau menawarkan lokasi, tipe rumah yang dibangun, fasilitas yang disediakan, serta harga dan cara pemilikan rumah yang berbeda-beda.

Oleh karena itu, paper ini bertujuan untuk mengidentifikasi determinan preferensi publik atau masyarakat dalam pemilihan lokasi perumahan terjangkau sehingga faktor determinan tersebut dapat dijadikan sebagai pertimbangan aspek yang harus disediakan oleh pengembang Kajian ini dilakukan di Banda Aceh dengan target responden adalah penduduk masuk ke Kota Banda Aceh. Determinan yang dikaji adalah faktor aksesibilitas, kelengkapan prasarana dan sarana, fasilitas, kondisi lingkungan, harga dan pelayanan, dan bangunan.

Metode analisis faktor Principle Component Analysis (PCA) digunakan untuk mengeksplorasi hubungan antar faktor dengan indikator pemilihan lokasi perumahan terjangkau. Uraian tentang metodologi pengambilan data, pengolahan dan analisis data dengan menggunakan PCA, interpretasi hasil dan kesimpulan disampaikan pada terakhir dari paper ini

\section{Metode Penelitian}

Objek penelitian adalah masyarakat pendatang ke kota Banda Aceh yang membeli perumahan melalui program pemerintah dengan skema rumah bersubsidi. Data yang dikumpulkan adalah data sosial-ekonomi dan persepsi responden terhadap faktor-faktor preferensi dalam menentukan lokasi perumahan. Pada penelitian ini diperkenalkan enam faktor (komponen) preferensi penentuan lokasi perumahan, yaitu (1) aksesibilitas; (2) kelengkapan prasarana dan sarana; (3) fasilitas; (4) kondisi lingkungan; (5) harga dan pelayanan; (6) bangunan. Sejumlah 48 indikator digunakan untuk memediasi persepsi masyarakat terhadap enam faktor di atas. Detail faktor dan masing-masing indikatornya dapat dilihat pada Tabel 1. Penentuan sampel diambil dari populasi penduduk masuk di Kota Banda Aceh yang sudah menghuni perumahan dari developer. Berdasarkan data dari Badan Pusat Statistik (BPS) Kota Banda Aceh (2017) jumlah penduduk masuk di Kota Banda Aceh diperoleh sebanyak 8.072 jiwa. Sampel diambil 150 dengan distribusi acak berstrata terlihat pada Tabel 2.

Teknik pengambilan sampel (sampling) yang digunakan dalam penelitian ini adalah proportionate stratified random sampling dan metode Stated Prefererence (SP) survei. Teknik SP banyak digunakan dalam pengambilan data kuisioner yang berupa indikator atau persepsi masyarakat. Penerapan pada kajian penerimaan masyarakat terhadap kebijakan transportasi (Sugiarto dkk. 2017a; 2017b; Idris dkk. 2019; Merfazi dkk. 2019), kajian tentang bangkitan pergerakan sepeda motor (Hikmi dkk. 2018; Balqis dkk. 2018; Dinda dkk. 2018) dan kajian tentang jalur evakusi pada skenario bencana dengan menggunakan metode SP juga dilakukan oleh Taufik dkk, (2018) dengan fokus kajian adalah pemilihan pemilihan moda

Determinan Preferensi Publik Dalam Pemilihan Lokasi Perumahan Terjangkau Bersubsidi di Kota Banda Aceh - Taufiq Saidi, Sugiarto Sugiarto, Muhammad Razuli, 
dan waktu evakuasi bencana di kecamatan Kuta Raja kota Banda Aceh. Pengumpulan data dengan SP survei juga digunakan dalam kajian kebijakan transportasi oleh Sugiarto dkk. (2017a; 2017b; 2018a; 2018b) dan Saleh dkk. (2016; 2019).

Tabel 1 Daftar operasional variabel dari faktor (komponen) dan indikatornya

\begin{tabular}{|c|c|c|c|}
\hline No. & Faktor & Indikator & Sumber \\
\hline 1 & Aksesibilitas & $\begin{array}{l}\text { Kedekatan terhadap tempat kerja } \\
\text { Kedekatan terhadap jalan utama } \\
\text { Kedekatan terhadap pusat kota } \\
\text { Kedekatan terhadap fasilitas perdagangan } \\
\text { Kedekatan terhadap sarana pendidikan } \\
\text { Kedekatan terhadap sarana pelayanan kesehatan } \\
\text { Kedekatan terhadap sarana pelayanan perbankan } \\
\text { Kedekatan terhadap kantor pemerintahan } \\
\text { Kedekatan terhadap tempat rekreasi/hiburan } \\
\text { Kedekatan terhadap tempat olah raga } \\
\text { Kedekatan terhadap terminal }\end{array}$ & Asteriani (2011) \\
\hline 2 & $\begin{array}{l}\text { Kelengkapan } \\
\text { prasarana } \\
\text { dan sarana }\end{array}$ & $\begin{array}{l}\text { Tersedianya jaringan jalan } \\
\text { Tersedianya jaringan listrik lingkungan dan hunian } \\
\text { Tersedianya jaringan telepon } \\
\text { Tersedianya jaringan air bersih } \\
\text { Tersedianya jaringan drainase } \\
\text { Tersedianya sarana persampahan } \\
\text { Tersedianya hidran kebakaran }\end{array}$ & Riskiyah dkk. (2015) \\
\hline 3 & Fasilitas & $\begin{array}{l}\text { Fasilitas peribadatan yang memadai } \\
\text { Ketersediaan taman yang memadai } \\
\text { Ketersediaan sarana olahraga } \\
\text { Ketersediaan pos hansip/siskamling } \\
\text { Kantor pos hansip dekat dengan warga }\end{array}$ & Riskiyah dkk. (2015) \\
\hline 4 & $\begin{array}{l}\text { Kondisi } \\
\text { lingkungan }\end{array}$ & $\begin{array}{l}\text { Keamanan } \\
\text { Kenyamanan } \\
\text { Kebersihan } \\
\text { Keindahan } \\
\text { Mempunyai kualitas permukaan jalan lingkungan } \\
\text { yang baik } \\
\text { Mempunyai lebar jalan lingkungan yang memadai } \\
\text { Lokasi tidak terlalu terganggu kebisingan } \\
\text { Bukan daerah banjir } \\
\text { Kemudahan mencapai lokasi tanpa hambatan yang } \\
\text { berarti } \\
\text { Adanya penerangan jalan lingkungan }\end{array}$ & Asteriani (2011) \\
\hline \multirow[t]{2}{*}{5} & $\begin{array}{l}\text { Harga dan } \\
\text { pelayanan }\end{array}$ & $\begin{array}{l}\text { Harga sesuai sarana dan prasarana yang ditawarkan } \\
\text { Harga sesuai dengan fasilitas yang ada } \\
\text { Pengawasan developer selama pengerjaan } \\
\text { Kecepatan developer menerima keluhan }\end{array}$ & Riskiyah dkk. (2015) \\
\hline & & $\begin{array}{l}\text { Harga perumahan terjangkau } \\
\text { Kemudahan pengajuan kredit } \\
\text { Penetapan biaya DP dan kemudahan pembayaran DP } \\
\text { Pemberian diskon } \\
\text { Pemberian bonus hadiah } \\
\text { Kualitas pelayanan }\end{array}$ & Asteriani (2011) \\
\hline 6 & Bangunan & $\begin{array}{l}\text { Letak ruang sesuai keinginan } \\
\text { Desain bangunan sesuai keinginan }\end{array}$ & Riskiyah dkk. (2015) \\
\hline & at & $\begin{array}{l}\text { si Publik Dalam Pemilihan Lokasi Perumaha } \\
\text { inda Aceh - Taufiq Saidi, Sugiarto Sugiarto, Muha }\end{array}$ & $\begin{array}{l}\text { Terjangkau } \\
\text { lad Razuli, }\end{array}$ \\
\hline
\end{tabular}


Rumah memiliki ventilasi yang baik untuk sirkulasi udara dan pencahayaan

Mempunyai area parkir Mempunyai keabsahan kepemilikan rumah

Asteriani (2011)

Tabel 2 Distribusi populasi dan sampel

\begin{tabular}{cccc}
\hline No. & Kecamatan & Populasi & Sampel \\
\hline 1 & Meuraxa & 1.139 & $(1.139 / 8.072) \times 150=21$ \\
2 & Jaya Baru & 1.484 & $(1.484 / 8.072) \times 150=28$ \\
3 & Banda Raya & 978 & $(978 / 8.072) \times 150=18$ \\
4 & Baiturrahman & 943 & $(943 / 8.072) \times 150=18$ \\
5 & Lueng Bata & 630 & $(630 / 8.072) \times 150=12$ \\
6 & Kuta Alam & 641 & $(641 / 8.072) \times 150=12$ \\
7 & Kuta Raja & 670 & $(670 / 8.072) \times 150=12$ \\
8 & Syiah Kuala & 972 & $(972 / 8.072) \times 150=18$ \\
9 & Ulee Kareng & 615 & $(615 / 8.072) \times 150=11$ \\
\hline \multicolumn{7}{c}{ Jumlah } & 8.072 & 150 \\
\hline
\end{tabular}

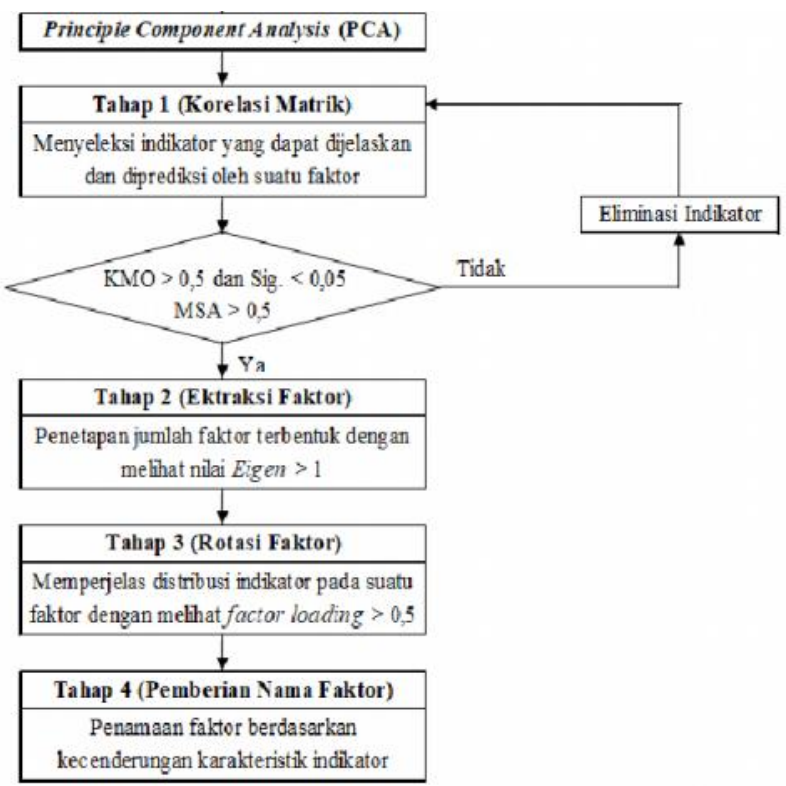

Gambar 1. Tahapan analisis data dengan PCA

\subsection{Pengolahan Data dan Analisis}

Pengolahan data yang dilakukan adalah analisis deskriptif dari data karakteristik responden dan persepsi masyarakat. Analisis data digunakan Principle Component Analysis (PCA) untuk mengevaluasi indikator-indikator beserta faktor-faktor keputusan konsumen dalam pemilihan lokasi perumahan di Kota Banda Aceh. Pada PCA, faktor yang dijelaskan di Tabel 1 akan di rotasi kembali. Sehingga faktor (komponen) akan dinamakan kembali berdasarkan matrik korelasi hasil dari rotasi dengan konsep PCA. Indikator yang ada dalam faktor tersebut dievaluasi, untuk diketahui faktor yang relevan atau diperoleh faktor baru. Secara umum langkah-langkah metode pengumpulan data dan analisis dilakukan sesuai dengan tahapan pada Gambar 1. Adapun tahapan-tahapan

Determinan Preferensi Publik Dalam Pemilihan Lokasi Perumahan Terjangkau Bersubsidi di Kota Banda Aceh - Taufiq Saidi, Sugiarto Sugiarto, Muhammad Razuli, 
analisis faktor dengan PCA mengacu pada Gambar 1 adalah (1) melakukan pengujian korelasi matrik untuk melihat pengaruh indikator terhadap kandidat faktor/komponen; (2) tahap korelasi matrik ini dilakukan beberapa kali percobaan hingga semua indikator memiliki nilai Kaiser-Meyer-Olkin (KMO) $>0,5$ dan Signifikan pada 5\% interval kesalahan serta nilai Measure of Sampling Adequacy (MSA) > 0,5; (3) melakukan ekstraksi faktor batas nilai eigen value > 1; (4) melakukan rotasi faktor melihat konsistensi indikator terhadap kandidat faktor, (5) menentukan nama faktor berdasarkan hasil dari langkah (4).

\section{Hasil dan Pembahasan}

\subsection{Distribusi Karakteristik Sosial-ekonomi Responden}

Karakteristik dari 150 target responden berdasarkan jenis kelamin menunjukkan bahwa sebagian besar responden berjenis kelamin pria sebanyak 104 orang $(69,33 \%)$ dan sisanya berjenis kelamin wanita sebanyak 46 orang $(30,67 \%)$. Untuk usia responden, sebagian besar responden dengan umur 31-40 tahun sebanyak 77 orang (51,33\%), kemudian dengan umur 41-50 tahun sebanyak 65 orang $(43,33 \%)$ dan sisanya responden dengan umur 20-30 tahun sebanyak 8 orang $(5,33 \%)$. Meninjau dari sisi pendidikan, menunjukkan bahwa hampir setengah responden dengan pendidikan S1 sebanyak 56 orang $(37,33 \%)$, diikuti responden dengan pendidikan D3 sebanyak 55 orang $(36,67 \%)$. Sebagian kecil responden dengan pendidikan SMA/sederajat sebanyak 32 orang $(21,33 \%)$, dan sisanya responden dengan pendidikan S2 sebanyak 7 orang $(4,67 \%)$. Untuk pekerjaan, distribusi data menunjukkan bahwa responden dengan pekerjaan swasta sebanyak 49 orang $(32,67 \%)$. Sebagian kecil responden dengan pekerjaan wiraswasta sebanyak 39 orang $(26,00 \%)$, diikuti responden dengan pekerjaan pegawai pemerintah sebanyak 32 orang $(21,33 \%)$, sisanya adalah ibu rumah tangga sebanyak 30 orang $(20,00 \%)$.

\subsection{Reliabilitas Faktor Determinan}

Pengujian reliabilitas dilakukan untuk mengetahui variabel dalam hal ini item/indikator yang digunakan untuk memediasi faktor determinan pemilihan lokasi perumahan bersubsidi yang dipilih oleh responden. Item pada kuesioner dapat dipercaya (reliabel) atau tidak berdasarkan data isian yang diterima dari responden memenuhi pengujian Cronbach Alpha. Jika nilai Cronbach Alpha > 0,6 maka item disetiap faktor telah memenuhi syarat pengujian reliabilitas. Hasil pengujian reliabilitas terhadap faktor dapat dilihat pada Tabel 3. Tabel 3 menunjukkan bahwa semua item pertanyaan pada kuesioner telah memenuhi syarat reliabilitas (Cronbach Alpha > 0,6).

Tabel 3. Hasil pengujian reliabilitas item

\begin{tabular}{clcc}
\hline No. & \multicolumn{1}{c}{ Variabel } & $\begin{array}{c}\text { Cronbach } \\
\text { Alpha }>0,6\end{array}$ & Keterangan \\
\hline 1 & Faktor aksesibilitas $\left(\mathrm{X}_{1}\right)$ & 0,916 & Reliabel \\
2 & Faktor kelengkapan prasarana dan sarana $\left(\mathrm{X}_{2}\right)$ & 0,936 & Reliabel \\
3 & Faktor fasilitas $\left(\mathrm{X}_{3}\right)$ & 0,892 & Reliabel \\
4 & Faktor kondisi lingkungan $\left(\mathrm{X}_{4}\right)$ & 0,603 & Reliabel \\
5 & Faktor harga dan pelayanan $\left(\mathrm{X}_{5}\right)$ & 0,604 & Reliabel \\
6 & Faktor bangunan $\left(\mathrm{X}_{6}\right)$ & 0,606 & Reliabel \\
\hline
\end{tabular}

Determinan Preferensi Publik Dalam Pemilihan Lokasi Perumahan Terjangkau Bersubsidi di Kota Banda Aceh - Taufiq Saidi, Sugiarto Sugiarto, Muhammad Razuli, 


\subsection{Hasil Analisa Faktor dengan PCA}

Tabel 4 memperlihatkan bahwa komponen yang mempunyai nilai eigen value > 1 mewakili total varian sebesar 83,07, yaitu komponen 1 hingga 8 . Komponen dengan nilai eigen value $>1$ kemudian dipilih dan di ekstraksi guna mendapatkan indikator yang paling berpengaruh terhadap masing-masing faktor terpilih. Tahap rotasi faktor ini dilakukan untuk memperjelas distribusi indikator yang masuk ke dalam suatu kelompok faktor. Rotasi faktor digunakan metode varimax dimana nilai loading factor diambil $\geq 0,5$. Hasil rotasi faktor dengan menggunakan metode varimax dapat dilihat pada Tabel 5. Tabel 5 menunjukkan hasil dari rotasi faktor dan hubungannya dengan indikator-indikator di masingmasing faktor yang secara statistik (korelasi matrik) signifikan mempengaruhi terhadap faktor 1 hingga 8 . Hasil rotasi faktor menunjukkan faktor dengan indikator signifikan hanya diperoleh pada faktor 1 hingga 7, sementara faktor 8 tidak diperoleh indikator yang signifikan mempengaruhinya (loading factor < $0.5)$.

Tabel 4 Ekstraksi faktor dan penentuan total varian komponen yang

\begin{tabular}{|c|c|c|c|c|c|c|}
\hline \multirow[b]{2}{*}{ Faktor* } & \multicolumn{3}{|c|}{ Nilai Eigen Value } & \multicolumn{3}{|c|}{ Ekstraksi Faktor } \\
\hline & Total & $\begin{array}{l}\text { Varians } \\
(\%)\end{array}$ & $\begin{array}{c}\text { Kumulatif } \\
(\%)\end{array}$ & Total & $\begin{array}{l}\text { Varians } \\
(\%)\end{array}$ & $\begin{array}{c}\text { Kumulatif } \\
(\%)\end{array}$ \\
\hline 1 & 11,159 & 24,798 & 24,798 & 11,159 & 24,798 & 24,798 \\
\hline 2 & $\mathbf{8 , 5 2 7}$ & 18,948 & 43,746 & $\mathbf{8 , 5 2 7}$ & 18,948 & 43,746 \\
\hline 3 & 7,427 & 16,505 & 60,251 & 7,427 & 16,505 & 60,251 \\
\hline 4 & 3,852 & 8,561 & 68,811 & 3,852 & 8,561 & 68,811 \\
\hline 5 & 2,904 & 6,454 & 75,265 & 2,904 & 6,454 & 75,265 \\
\hline 6 & 1,412 & 3,139 & 78,404 & 1,412 & 3,139 & 78,404 \\
\hline 7 & 1,068 & 2,374 & 80,778 & 1,068 & 2,374 & 80,778 \\
\hline 8 & 1,029 & 2,288 & 83,066 & 1,029 & 2,288 & 83,066 \\
\hline 9 & 0,966 & 2,147 & 85,213 & & & \\
\hline 10 & 0,805 & 1,790 & 87,003 & & & \\
\hline 11 & 0,676 & 1,502 & 88,504 & & & \\
\hline 12 & 0,601 & 1,336 & 89,840 & & & \\
\hline 13 & 0,560 & 1,243 & 91,083 & & & \\
\hline 14 & 0,448 & 0,996 & 92,079 & & & \\
\hline . & . & . & . & & & \\
\hline 43 & 0,006 & 0,013 & 99,987 & & & \\
\hline 44 & 0,003 & 0,008 & 99,994 & & & \\
\hline 45 & 0,002 & 0,006 & 100,000 & & & \\
\hline
\end{tabular}

*Varian dengan nilai eigen value > 1 ditebalkan (bold) dan menjadi faktor terpilih; faktor No. 15-42 tidak disampaikan untuk mengurangi panjang tabel.

Tahap selanjutnya adalah pemberian nama faktor berdasarkan indikatorindikator yang signifikan pada masing-masing faktor. Berdasarkan indikatorindikator yang telah terpilih pada masing-masing faktor nama indikator yang terpilih ada tujuh yaitu (1) faktor aksesibilitas dan pelayanan; (2) faktor kelengkapan prasarana dan sarana; (3) faktor fasilitas dan kepemilikan rumah; (4) faktor kondisi lingkungan; (5) faktor harga dan desain; (6) faktor kondisi jalan; dan (7) faktor kesesuaian harga. Hasil empiris dengan menggunakan PCA menunjukkan pemilihan lokasi perumahan bersubsidi di Banda Aceh oleh para penduduk pendatang sangat dipengaruhi oleh ketujuh faktor tersebut. Faktor aksesibilitas dan pelayanan, kelengkapan prasarana dan sarana dan fasilitas dan

Determinan Preferensi Publik Dalam Pemilihan Lokasi Perumahan Terjangkau Bersubsidi di Kota Banda Aceh - Taufiq Saidi, Sugiarto Sugiarto, Muhammad Razuli, 
kepemilikan rumah menjadi faktor paling menentukan pemilihan tersebut. Untuk indikator-indikator yang paling berpengaruh disetiap faktor dan total kontribusi varian disetiap faktor dapat dilihat pada Tabel 6.

Tabel 5 Rotasi Faktor dengan menggunakan varimax

\begin{tabular}{|c|c|c|c|c|c|c|c|c|}
\hline & \multicolumn{8}{|c|}{ Faktor terpilih* } \\
\hline & 1 & 2 & 3 & 4 & 5 & 6 & 7 & 8 \\
\hline Indikator 1 & $\mathbf{0 , 8 0 5}$ & $-0,221$ & 0,303 & $-0,220$ & 0,069 & $-0,010$ & $-0,083$ & $-0,030$ \\
\hline Indikator 2 & 0,731 & 0,546 & 0,119 & $-0,244$ & $-0,020$ & 0,195 & 0,001 & $-0,110$ \\
\hline Indikator 3 & 0,733 & 0,503 & 0,110 & $-0,230$ & $-0,027$ & 0,219 & 0,039 & $-0,053$ \\
\hline Indikator 4 & 0,828 & $-0,107$ & $-0,217$ & $-0,043$ & 0,016 & 0,042 & 0,115 & 0,172 \\
\hline Indikator 5 & 0,709 & $-0,163$ & $-0,285$ & $-0,108$ & 0,359 & $-0,193$ & 0,153 & 0,184 \\
\hline Indikator 7 & 0,708 & 0,383 & $-0,270$ & 0,088 & 0,110 & $-0,330$ & 0,191 & 0,035 \\
\hline Indikator 8 & 0,784 & 0,375 & $-0,119$ & 0,181 & $-0,317$ & $-0,007$ & 0,105 & $-0,012$ \\
\hline Indikator 9 & 0,864 & $-0,411$ & $-0,038$ & $-0,110$ & $-0,019$ & $-0,043$ & $-0,065$ & 0,042 \\
\hline Indikator 10 & 0,651 & 0,513 & 0,188 & 0,325 & 0,049 & 0,212 & $-0,201$ & $-0,029$ \\
\hline Indikator 11 & 0,775 & 0,500 & 0,002 & 0,046 & $-0,085$ & $-0,158$ & 0,126 & $-0,098$ \\
\hline Indikator 12 & $-0,045$ & 0,813 & 0,192 & $-0,189$ & $-0,193$ & 0,092 & 0,274 & $-0,226$ \\
\hline Indikator 13 & $-0,013$ & 0,848 & 0,055 & $-0,197$ & 0,313 & 0,048 & 0,123 & $-0,060$ \\
\hline Indikator 14 & 0,005 & 0,761 & 0,219 & 0,339 & $-0,006$ & 0,083 & $-0,255$ & 0,117 \\
\hline Indikator 15 & 0,050 & 0,890 & 0,072 & $-0,150$ & $-0,032$ & 0,181 & 0,012 & 0,039 \\
\hline Indikator 16 & 0,110 & 0,759 & $-0,199$ & 0,020 & $-0,113$ & 0,138 & 0,097 & 0,306 \\
\hline Indikator 17 & 0,106 & 0,766 & $-0,388$ & 0,073 & $-0,095$ & 0,200 & 0,162 & $-0,108$ \\
\hline Indikator 18 & 0,064 & 0,894 & 0,130 & $-0,144$ & $-0,026$ & 0,179 & $-0,042$ & $-0,137$ \\
\hline Indikator 19 & $-0,075$ & 0,789 & $-0,004$ & $-0,202$ & 0,297 & $-0,067$ & 0,074 & 0,189 \\
\hline Indikator 20 & $-0,244$ & 0,132 & 0,737 & 0,362 & $-0,033$ & $-0,087$ & $-0,127$ & $-0,199$ \\
\hline Indikator 21 & 0,333 & $-0,291$ & 0,724 & 0,289 & $-0,184$ & $-0,057$ & 0,087 & $-0,075$ \\
\hline Indikator 22 & $-0,155$ & 0,202 & 0,688 & 0,385 & 0,189 & 0,183 & $-0,356$ & $-0,014$ \\
\hline Indikator 23 & $-0,333$ & 0,046 & 0,786 & 0,356 & $-0,240$ & $-0,094$ & 0,055 & 0,017 \\
\hline Indikator 24 & 0,332 & $-0,272$ & 0,745 & 0,285 & $-0,242$ & $-0,089$ & 0,097 & 0,049 \\
\hline Indikator 25 & $-0,089$ & $-0,081$ & 0,162 & 0,864 & 0,100 & 0,191 & $-0,004$ & 0,067 \\
\hline Indikator 26 & $-0,280$ & $-0,267$ & 0,198 & 0,733 & $-0,298$ & $-0,184$ & 0,240 & 0,017 \\
\hline Indikator 27 & $-0,086$ & $-0,070$ & 0,168 & 0,747 & 0,122 & 0,044 & $-0,226$ & $-0,246$ \\
\hline Indikator 28 & $-0,248$ & $-0,224$ & 0,158 & 0,746 & $-0,269$ & $-0,127$ & 0,300 & 0,057 \\
\hline Indikator 29 & $-0,127$ & 0,338 & $-0,037$ & 0,133 & 0,081 & 0,816 & $-0,100$ & 0,062 \\
\hline Indikator 30 & 0,192 & 0,236 & 0,081 & 0,114 & 0,153 & 0,718 & 0,061 & $-0,077$ \\
\hline Indikator 31 & $-0,100$ & $-0,043$ & 0,104 & 0,836 & 0,172 & 0,212 & 0,023 & 0,089 \\
\hline Indikator 33 & $\mathbf{0 , 7 3 3}$ & 0,286 & $-0,485$ & $-0,046$ & $-0,149$ & 0,048 & 0,007 & 0,011 \\
\hline Indikator 34 & 0,156 & 0,472 & $-0,586$ & $-0,026$ & 0,308 & $-0,162$ & 0,123 & 0,121 \\
\hline Indikator 35 & 0,856 & $-0,415$ & $-0,026$ & $-0,077$ & $-0,019$ & $-0,040$ & $-0,055$ & 0,022 \\
\hline Indikator 36 & 0,071 & 0,378 & $-0,088$ & 0,125 & 0,028 & 0,001 & 0,701 & 0,000 \\
\hline Indikator 38 & 0,735 & $-0,086$ & 0,557 & $-0,257$ & 0,108 & 0,117 & $-0,064$ & 0,032 \\
\hline Indikator 39 & 0,038 & 0,295 & 0,097 & 0,148 & 0,655 & 0,277 & 0,009 & 0,141 \\
\hline Indikator 40 & 0,022 & 0,301 & 0,715 & 0,135 & 0,253 & 0,166 & $-0,008$ & $-0,091$ \\
\hline Indikator 41 & 0,772 & 0,229 & $-0,065$ & $-0,133$ & $-0,072$ & 0,072 & $-0,031$ & $-0,059$ \\
\hline Indikator 42 & 0,723 & $-0,039$ & 0,528 & $-0,231$ & 0,143 & 0,124 & $-0,013$ & 0,043 \\
\hline Indikator 43 & 0,493 & $-0,477$ & 0,092 & $-0,022$ & $-0,402$ & $-0,197$ & 0,376 & 0,098 \\
\hline Indikator 44 & 0,017 & $-0,085$ & $-0,280$ & 0,070 & 0,610 & $-0,017$ & $-0,007$ & $-0,106$ \\
\hline Indikator 45 & 0,378 & $-0,111$ & 0,556 & 0,241 & $-0,196$ & $-0,048$ & $-0,199$ & 0,474 \\
\hline Indikator 46 & 0,320 & 0,189 & $-0,114$ & 0,401 & $-0,536$ & $-0,226$ & 0,063 & 0,314 \\
\hline Indikator 48 & $-0,130$ & 0,221 & 0,646 & $-0,162$ & $-0,241$ & $-0,038$ & 0,247 & 0,436 \\
\hline Indikator 49 & $-0,040$ & 0,457 & 0,694 & $-0,210$ & 0,070 & 0,158 & $-0,088$ & 0,282 \\
\hline
\end{tabular}

* Indikator yang signifikan berpengaruh terhadap masing-masing faktor ditebalkan. 
Tabel 6 memperlihatkan bahwa terdapat 7 faktor yang mempengaruhi pemilihan lokasi perumahan di Banda Aceh yaitu faktor aksesibilitas dan pelayanan, faktor prasarana dan sarana, faktor fasilitas dan kepemilikan rumah, faktor kondisi lingkungan, faktor harga dan desain, faktor kondisi jalan, dan faktor kesesuaian harga. Varian oleh faktor aksesibilitas dan pelayanan sebesar $24,80 \%$, faktor kelengkapan prasarana dan sarana sebesar $18,95 \%$, faktor fasilitas dan kepemilikan rumah sebesar $16,51 \%$, faktor kondisi lingkungan sebesar $8,56 \%$, faktor harga dan desain sebesar $6,44 \%$, faktor kondisi jalan sebesar $3,14 \%$, dan faktor kesesuaian harga sebesar 2,37\%. Total varians yang bisa dijelaskan oleh 7 faktor tersebut sebesar 80,78\%, sedangkan sisa sebesar 19,23\% terdapat pada faktor lainnya yang tidak terakomodir pada penelitian ini.

Tabel 6. Faktor-faktor dalam Pemilihan Lokasi Perumahan

\begin{tabular}{|c|c|c|c|}
\hline No. & Faktor & Indikator & Varians \\
\hline 1 & $\begin{array}{l}\text { Aksesibilitas } \\
\text { dan } \\
\text { pelayanan }\end{array}$ & $\begin{array}{l}\text { Kedekatan terhadap tempat kerja (indikator 1) } \\
\text { Kedekatan terhadap jalan utama (indikator 2) } \\
\text { Kedekatan terhadap pusat kota (indikator 4) } \\
\text { Kedekatan terhadap fasilitas perdagangan (indikator 5) } \\
\text { Kedekatan terhadap sarana pendidikan (indikator 7) } \\
\text { Kedekatan terhadap pelayanan perbankan (indikator 8) } \\
\text { Kedekatan terhadap kantor pemerintahan (indikator 1) } \\
\text { Kedekatan terhadap tempat rekreasi/hiburan (indikator 9) } \\
\text { Kedekatan terhadap tempat olah raga (indikator 10) } \\
\text { Kedekatan terhadap terminal (indikator 11) } \\
\text { Kemudahan mencapai lokasi tanpa hambatan (indikator 33) } \\
\text { Harga sesuai sarana/prasarana ditawarkan (indikator 35) } \\
\text { Kecepatan developer menerima keluhan (indikator 38) } \\
\text { Penetapan biaya/kemudahan pembayaran DP (indikator 41) } \\
\text { Pemberian diskon (indikator 42) } \\
\text { Pemberian bonus hadiah (indikator 43) }\end{array}$ & $24,80 \%$ \\
\hline 2 & $\begin{array}{c}\text { Kelengkapan } \\
\text { prasarana } \\
\text { dan sarana }\end{array}$ & $\begin{array}{l}\text { Tersedianya jaringan jalan (indikator 12) } \\
\text { Tersedianya jaringan listrik dan hunian (indikator 13) } \\
\text { Tersedianya jaringan telepon (indikator 14) } \\
\text { Tersedianya jaringan air bersih (indikator 15) } \\
\text { Tersedianya jaringan drainase (indikator 16) } \\
\text { Tersedianya jaringan sanitasi (indikator 17) } \\
\text { Tersedianya sarana persampahan (indikator 18) } \\
\text { Tersedianya hidran kebakaran (indikator 19) }\end{array}$ & $18,95 \%$ \\
\hline 3 & $\begin{array}{c}\text { Fasilitas dan } \\
\text { kepemilikan } \\
\text { rumah }\end{array}$ & $\begin{array}{l}\text { Fasilitas peribadatan yang memadai (indikator 21) } \\
\text { Ketersediaan taman yang memadai (indikator 22) } \\
\text { Ketersediaan sarana olahraga (indikator 23) } \\
\text { Ketersediaan pos hansip/siskamling (indikator 24) } \\
\text { Kantor pos hansip dekat dengan warga (indikator 34) } \\
\text { Adanya penerangan jalan lingkungan (indikator 40) } \\
\text { Kemudahan pengajuan kredit (indikator 42) } \\
\text { Letak ruang sesuai keinginan (indikator 45) } \\
\text { Mempunyai area parkir (indikator 48) } \\
\text { Mempunyai keabsahan kepemilikan rumah (indikator 49) }\end{array}$ & $16,51 \%$ \\
\hline 4 & $\begin{array}{c}\text { Kondisi } \\
\text { lingkungan }\end{array}$ & $\begin{array}{l}\text { Keamanan (indikator 25) } \\
\text { Kenyamanan (indikator 26) } \\
\text { Kebersihan dan keindahan (indikator 27) } \\
\text { Lokasi tidak terlalu terganggu kebisingan (indikator 28) }\end{array}$ & $8,56 \%$ \\
\hline
\end{tabular}

Determinan Preferensi Publik Dalam Pemilihan Lokasi Perumahan Terjangkau Bersubsidi di Kota Banda Aceh - Taufiq Saidi, Sugiarto Sugiarto, Muhammad Razuli, 


\begin{tabular}{cclc}
\hline 5 & $\begin{array}{c}\text { Harga } \\
\text { dan desain }\end{array}$ & $\begin{array}{l}\text { Harga perumahan terjangkau (indikator 39) } \\
\text { Kualitas pelayanan (indikator 44) } \\
\text { Desain bangunan sesuai keinginan (indikator 46) }\end{array}$ & $\mathbf{6 , 4 4 \%}$ \\
\hline 6 & $\begin{array}{c}\text { Kondisi } \\
\text { jalan }\end{array}$ & $\begin{array}{l}\text { Mempunyai kualitas jalan lingkungan baik (indikator 29) } \\
\text { Mempunyai lebar jalan yang memadai (indikator 30) }\end{array}$ & $\mathbf{3 , 1 4 \%}$ \\
\hline 7 & $\begin{array}{c}\text { Kesesuaian } \\
\text { harga }\end{array}$ & Harga sesuai dengan fasilitas yang ada (indikator 36) & $\mathbf{2 , 3 7 \%}$ \\
& & & \\
\hline
\end{tabular}

\subsection{Pembahasan Hasil Analisa Faktor}

Varian yang mempengaruhi keputusan pemilihan lokasi perumahan oleh masyarakat pendatang di Banda Aceh adalah faktor aksesibilitas dan pelayanan yaitu sebesar $24,80 \%$. Adapun indikator yang paling mempengaruhi faktor ini adalah indikator 1 (kedekatan terhadap tempat kerja) dengan koefisien sebesar 0.805 , indikator 4 (kedekatan terhadap fasilitas perdagangan) dengan koefisien sebesar 0.803, indikator 9 (kedekatan terhadap tempat rekreasi/hiburan) dengan keefosien sebesar 0.864 dan indikator 35 (harga sesuai sarana dan prasarana yang ditawarkan) dengan koefisien 0.856. Ini menunjukkan bahwa masyarakat cenderung memilih lokasi perumahan karena faktor aksesbilitas kepusat perbelanjaan dan sarana dan prasarana yang ditawarkan oleh pengembang.

Varian kedua yang berkontribusi signifikan terhadap keputusan pemilihan lokasi perumahan adalah faktor kelengkapan prasarana dan sarana yaitu sebesar 18.95\%. Adapun indikator yang paling mempengaruhi faktor ini adalah indikator 12 (tersedianya jaringan jalan) dengan koefisien sebesar 0.813 , indikator 13 (tersedianya jaringan listrik dan hunian) dengan koefisien sebesar 0.848, indikator 15 (tersedianya jaringan air bersih) dengan koefosien sebesar 0.890 dan indikator 18 (tersedianya sarana persampahan) dengan koefisien 0.894 . Koefisien pada faktor sarana dan prasarana menunjukkan ketersediaan jaringan listrik, air bersih dan persampahan menjadi indikator utama penentu faktor ini. Selanjutnya faktor penentu lainnya yaitu fasilitas dan kepemilikan rumah sebesar $16,51 \%$, faktor kondisi lingkungan sebesar $8,56 \%$, faktor harga dan desain sebesar $6,44 \%$, faktor kondisi jalan sebesar 3,14\%, dan faktor kesesuaian harga sebesar 2,37\% lebih detail dapat dilihat pada Tabel 6 untuk indikatornya dan Tabel 5 untuk koefisien pengaruh indikatornya.

\section{Kesimpulan dan Saran}

\subsection{Kesimpulan}

Analisa faktor dengan menggunakan PCA untuk menentukan faktor yang berpengaruh terhadap keputusan konsumen (masyarakat) dalam memilih lokasi perumahan, hasil analisa empiris dapat ditarik beberapa kesimpulan. Hasil rotasi faktor dengan varimax diperoleh 7 faktor penentu yang signifikan mempengaruhi keputusan konsumen terhadap pemilihan lokasi perumahan di kota Banda Aceh yaitu (1) faktor aksesibilitas dan pelayanan; (2) faktor prasarana dan sarana; (3) faktor fasilitas dan kepemilikan rumah; (4) faktor kondisi lingkungan; (5) faktor harga dan desain; (6) faktor kondisi jalan dan (7) faktor kesesuaian harga. Total varian yang mampu dijelaskan oleh 7 faktor diatas sebesar $80,78 \%$, sedangkan sisa sebesar $19,22 \%$ terdapat pada faktor lainnya yang tidak terakomodir pada

Determinan Preferensi Publik Dalam Pemilihan Lokasi Perumahan Terjangkau Bersubsidi di Kota Banda Aceh - Taufiq Saidi, Sugiarto Sugiarto, Muhammad Razuli, 
penelitian ini. Varian yang paling dominan mempengaruhi keputusan konsumen adalah faktor aksesibilitas dan pelayanan yaitu sebesar $24,80 \%$ dengan indikator paling dominan adalah kedekatan terhadap tempat kerja (0.805), kedekatan terhadap fasilitas perdagangan (0.803), kedekatan terhadap tempat rekreasi/hiburan (0.864) dan harga sesuai sarana dan prasarana yang ditawarkan (0.856). Hasil analisa faktor menunjukkan bahwa masyarakat cenderung memilih lokasi perumahan karena faktor aksesibilitas ke pusat perbelanjaan dan sarana dan prasarana yang ditawarkan oleh pengembang seperti ketersediaan jaringan listrik, air bersih dan persampahan menjadi indikator utama penentu pemilihan lokasi oleh konsumen.

\subsection{Saran}

Ada beberapa saran yang dapat diberikan berdasarkan analisa faktor-faktor penentu keputusan terhadap keputusan konsumen (masyarakat) dalam memilih lokasi perumahan di kota Banda Aceh, yaitu pembangunan perumahan oleh pengembang perlu memperhatikan faktor aksesibilitas dari lokasi perumahan ke pusat perbelanjaan dan juga memperhatikan sarana dan prasarana yang ditawarkan oleh pengembang seperti ketersediaan jaringan listrik, air bersih dan persampahan hal ini disarankan karena indikator diatas sangat dominan mempengaruhi kepuasan konsumen dalam pemilihan lokasi perumahan. Sedangkan untuk penelitian selanjutnya faktor teknis bangunan seperti spesifikasi dan lokasi perumahan terhadap kerentanan bencana geologi (gempa bumi) perlu dikaji. Mengingat Aceh merupakan daerah dengan potensi bencana geologi seperti yang dilaporkan oleh beberapa peneliti terdahulu, diantaranya (Saidi dkk. 2018; Sarana dkk. 2015; Yunita dkk. 2018).

\section{Daftar Kepustakaan}

Asteriani, F. 2011. Preferensi penghuni perumahan di kota Pekanbaru dalam menentukan lokasi perumahan, Jurnal Ekonomi Pembangunan, 12(1), pp. 71-91.

Balqis, P., A., Anggraini, R., Sugiarto, S. 2018. Model bangkitan pergerakan pekerja berdasarkan tingkat pendapatan rumah tangga (studi kasus Kota Banda Aceh). Jurnal Arsip Rekayasa Sipil dan Perencanaan, 1(2), pp. 10-18.

BPS. 2017. Banda Aceh dalam Angka. Badan Pusat Statistik (BPS) Kota Banda Aceh.

Dinda, R.P., Anggraini, R., Sugiarto, S. 2018. Model bangkitan pergerakan rumah tangga bagi pengguna sepeda motor berdasarkan lokasi tujuan perjalanan di kota Banda Aceh. Jurnal Arsip Rekayasa Sipil dan Perencanaan, 1(3), pp. 19-30.

Glaeser, E.L. Gyourko, J. 2003. The impact of building restrictions on housing affordability. FRB New York - Economic Policy Review, 9 (2), pp. 21-39.

Hikmi, A., Anggraini, R., Sugiarto, S. 2018. Model bangkitan pergerakan penduduk di Kabupaten Aceh Barat Daya berdasarkan struktur rumah tangga dan pendapatan keluarga. Jurnal Arsip Rekayasa Sipil dan Perencanaan, 1(1), pp. 1-9.

Determinan Preferensi Publik Dalam Pemilihan Lokasi Perumahan Terjangkau Bersubsidi di Kota Banda Aceh - Taufiq Saidi, Sugiarto Sugiarto, Muhammad Razuli, Lulusi 
Idris, E., Sugiarto, S., Saleh, S.M. 2019. Analisa karakteristik sosial-ekonomi masyarakat terhadap efektivitas jembatan penyeberangan di kota Banda Aceh. Jurnal Arsip Rekayasa Sipil dan Perencanaan, 2(1), pp. 31-37.

Merfazi, M., Sugiarto, S., Anggraini, R. 2019. Persepsi masyarakat terhadap kebijakan Trans Koetaradja pada koridor pusat Kota-Mata Ie dan pusat Kota-Ajun-Lhoknga menggunakan indikator variabel laten. Jurnal Arsip Rekayasa Sipil dan Perencanaan, 2(1), pp. 58-67.

Riskiyah, I.R., Suryo E.A., Wijatmiko, I. 2015. Analisis kinerja developer terhadap kepuasan penghuni perumahan di Kota Malang, Jurnal Rekayasa Sipil, 9(2), pp. 115-120.

Saidi, T., Aulia, T.B., Setiawan, B., Abdullah, N., \& Hasan, M., 2018. Spectral displacement (SD) of Banda Aceh's soft soil for seismic vulnerability assessment. MATEC Web of Conferences, 197, 10001.

Saleh, M.S., Sugiarto S., Mutiawati, C., Angraini, R., Isya, M. 2016. Using psychometric data from the stated preference (SP) experiments to search explanatory power for appropriateness of congestion charging policy. Aceh International Journal of Science and Technology, 5(3), pp. 88-96.

Saleh, M.S., Sugiarto S., Angraini, R. 2019. Analysis on Public's Response Toward Bus Reform Policy in Indonesia Considering Latent Variables. The Open Transportation Journal, Volume 13, pp. 17-14.

Sugiarto, S., Miwa, T., Morikawa, T., 2017a. Inclusion of latent constructs in utilitarian resource allocation model for analyzing revenue spending options in congestion charging policy. Transportation Research Part A: Policy and Practice, 103, pp. 36-53.

Sugiarto, S., Miwa, T., Sato, H., Morikawa, T., 2017b. Explaining differences in acceptance determinants towards congestion charging policies in Indonesia and Japan. Journal of Urban Planning and Development (ASCE), 143(2), pp. 1-12.

Sugiarto, S., Miwa, T., Morikawa, T., 2018a. Recursive bivariate response models of the ex-ante intentions to link perceived acceptability among charge and refund options for alternative road pricing schemes. Transp. Lett.: Int. J. Transp. Res. 10(1), pp. 52-63.

Sugiarto, S., Miwa, T., Sato, H., Morikawa, T., 2018b. The tendency of public's attitudes to evaluate urban congestion charging policy in Asian megacity perspective: Case a study in Jakarta, Indonesia. Case Studies on Transport Policy. an article in press.

Sarana, D., Saidi, T., Muttaqin. 2015. Analisis respon spektra terhadap percepatan gerakan akibat gempa Aceh Tahun 2010-2013. Jurnal Teknik Sipil Universitas Syiah Kuala, Vol. 4, 229-240.

Taufik., Sugiarto, S., Insya, M. 2018. Analisa pemilihan moda dan waktu evakuasi bencana tsunami di kecamatan Kuta Raja Banda Aceh. Jurnal Arsip Rekayasa Sipil dan Perencanaan, 1(2), pp. 19-29.

Woo, A., Joh, K. Van Zandt, S. 2014. Impacts of the low-income housing tax credit program on neighborhood housing turnover. Urban Affairs Review, 52 (2), pp. 247-279.

Yunita, H., Setiawan, B., Saidi, T., \& Abdullah, N., 2018. Site response analysis for estimating seismic site amplification in the case of Banda Aceh Indonesia. MATEC Web of Conferences, 197, 10002.

Determinan Preferensi Publik Dalam Pemilihan Lokasi Perumahan Terjangkau Bersubsidi di Kota Banda Aceh - Taufiq Saidi, Sugiarto Sugiarto, Muhammad Razuli, 